their use, later extending to problems of searchlight design and automatic control. In 1940 he was transferred with the remainder of the Biggin Hill Establishment to Christchurch to join with the Army radar group which had been transferred from Bawdsey. There he became leader of the team responsible for the application of radar to the control of searchlights, the introduction of which into the Services made such a great improvement in searchlight operation. He continued in radar work when the Establishment (by then the Radar Research and Development Establishment) was transferred to Malvern, and was concerned with a number of Army radar projects throughout the War. In 1953, when the Radar Research and Development Establishment and the Telecommunication Research Establishment were combined as the Radar Research Establishment, he was promoted to deputy chief scientific officer and became head of the division responsible for ground radar for both the Army and the Royal Air Force. In 1954 he was appointed director of atomic weapons (development and production) at the Ministry of Supply Headquarters.

\section{Reactor Conference at Harwell}

The United Kingdom Atomic Energy Authority announces that a conference at Harwell will be held on November 30, a $s$ which its programme of research on advanced types of nuclear power reactor systems will be explained to representatives of British industry, and at which the salient features of the particular systems which have been chosen for investigation will be described. Accommodation will be available for about two hundred representatives from industry. Requests for further details and for reservations should be made to the Director (Industrial Collaboration Office), Atomic Energy Research Establishment, Harwell, Nr. Dideot, Berks, not later than August 31. The Authority intends that following this conference British firms wishing to do so may be kept informed of the general progress of work on these reactor systems. The information will be supplied at an annual conference on each system. Application for admission to this scheme should be made to the Industrial Collaboration Office at Harwell, from which further details may be obtained.

\section{Medical School at the University College of Rhodesia and Nyasaland}

THE University College of Rhodesia and Nyasaland has appointed a planning committee to advise the College on the establishment of a medical school, and the committee will make a preliminary visit to the Federation of Rhodesia and Nyasaland next January. The committee's terms of reference are : "To advise the University College of Rhodesia and Nyasaland on the desirability and practicability of establishing a medical school as an integral part of the College; to prepare proposals for the training curriculum, postgraduate training, the research facilities, the buildings, equipment and staffing required, including those required for a suitable teaching hospital and other centres for clinical facilities; to prepare estimates of the capital and recurrent costs involved and a phased time-table for development; and to make any other proposals and suggestions for the development of medical education and research under the auspices of the College". The members of the committee are as follows: L. Farrer-Brown, director of the Nuffield Foundation (chairman); Prof. W. Melville Arnott, William Withering professor of Medi- cine, University of Birmingham ; Prof. T. H. Davey, Middlemass Hunt professor of tropical hygiene, University of Liverpool ; Prof. A. D. M. Greenfield, Dunville professor of physiology, The Queen's University of Belfast; Prof. P. B. Medawar, Jodrell professor of zoology, University College, London ; Prof. R. Milnes Walker, professor of surgery, University of Bristol ; and the Hon. Honor M. V. Smith, May reader in medicine, University of Oxford.

\section{University Foundation of Brussels : Report for 1954-55}

THE thirty-fifth annual report of the University Foundation of Belgium, covering the year 1954-55 (pp. 153. Bruxelles: Fondation Universitaire), records that the Foundation made grants to 242 first-year students (of whom 45 were women), 561 to students in their second or subsequent years (105 women) and 971 grants were renewed (163 women). Of these grants, which totalled $5,843,000$ francs, the great majority were at the Universities of Brussels (308), Ghent (331), Liège (269) or Louvain (653), the remainder being distributed among some fourteen other institutions, and all but thirty-six were for 3,000 francs. Students of medicine (469) received the largest number of grants, the next being engineering. (253), philosophy and letters (242), science (241), commercial sciences, economics and finance (171) and law (165). Over the period 1930-55, 81 per cent of the grants were totally reimbursed. Some travel grants were awarded in 1954-55, and subsidies for scientific works and periodicals amounted to $1,984,000$ francs, of which $1,559,500$ francs was for periodicals. Subsidies to scientific or university associations amounted to 541,000 francs, and the report includes a list of institutions with which the Foundation has arranged the exchange of publications during the academic year and also a list of periodicals of which the Foundation has guaranteed a regular service to the scientific libraries of Belgium. In addition, statistics are included for the universities and high schools of Belgium. The number of students was 38,498 , compared with 35,689 in $1953-54$, and of these, 22,299 were pursuing courses in ancient humanities and 16,199 courses in modern humanities. Only 1,789 men and 646 women were taking science courses, 5,657 men and 1,1.52 women taking medicine or pharmacy, and 2,621 men and 20 women taking applied science, arts or manufactures.

\section{Natural Resources, Food and Population in Inter- Tropical Africa}

THe International Geographical Union has published, under the title "National Resources, Food and Population in Inter-Tropical Africa", a report of a symposium held at Makerere College, Kampala, during September 10-17, 1955, with the financial support of the United Nations Educational Scientific and Cultural Organization (pp. 104. Bude: Geographical Publications, Ltd.; also Department of Geography, Makerere College, P.O. Box 262, Kampala, Uganda, 1956 ; 5s.). The president of the Union, Prof. L. Dudley Stamp, explains in a foreword that the symposium was designed to bring together workers in one of the major under-developed regions of the world and to concentrate on a study of the problems of the region. The report outlines the programme and gives the membership of the symposium, as well as summaries of the twenty-one papers read, but not of the discussions. These papers include a geographical appraisal of Buganda, by Prof. 